\title{
Clinical data and basal gonadotropins in the diagnosis of central precocious puberty in girls
}

\author{
Teodoro Durá-Travé1,2,3, Fidel Gallinas-Victoriano², María Malumbres-Chacon², Lotfi Ahmed-Mohamed², \\ María Jesús Chueca-Guindulain ${ }^{2,3}$ and Sara Berrade-Zubiri' ${ }^{2,3}$
}

${ }^{1}$ Department of Pediatrics, School of Medicine, University of Navarra, Pamplona, Spain

${ }^{2}$ Department of Pediatrics, Navarra Hospital Complex, Pamplona, Spain

${ }^{3}$ Navarra Institute for Health Research (IdisNA), Pamplona, Spain

Correspondence should be addressed to T Durá-Travé: tduratra@cfnavarra.es

\begin{abstract}
Objective: The objective of this study was to analyze whether some auxological characteristics or a single basal gonadotropin measurement will be sufficient to distinguish the prepubertal from pubertal status.

Methods: Auxologycal characteristics were recorded and serum LH and FSH were measured by immunochemiluminescence assays before and after GnRH stimulation test in a sample of 241 Caucasian girls with breast budding between 6- and 8-years old. Peak LH levels higher than 5 IU/L were considered a pubertal response. Area under the curve, cut-off points, sensitivity, and specificity for auxologycal variables and basal gonadotropins levels were determined by receiver operating curves.

Results: There were no significant differences in age at onset, weight, height, BMI and height velocity between both groups. Bone age was significantly higher in pubertal girls $(P<0.05)$, although with limited discriminatory capacity. The sensitivity and specificity for the basal LH levels were 89 and $82 \%$, respectively, for a cut off point of $0.1 \mathrm{IU} / \mathrm{L}$. All girls in the pubertal group had a basal LH higher than $1.0 \mathrm{IU} / \mathrm{L}$ (positive predictive value of $100 \%)$. There was a wide overlap of basal FSH and LH/FSH ratio between prepubertal and pubertal girls.

Conclusions: Auxologycal characteristics should not be used only in the differential diagnosis between prepubertal from pubertal status in 6- to 8-year-old girls. We found a high specificity of a single basal LH sample and it would be useful for establishing the diagnosis of puberty in this age group, reducing the need for GnRH stimulation testing.
\end{abstract}

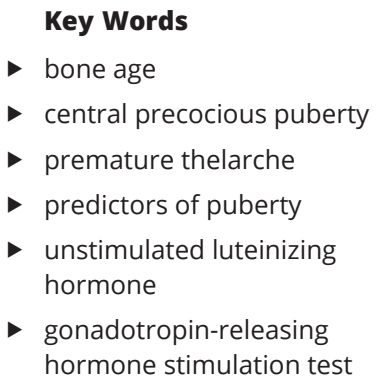

Endocrine Connections (2021) 10, 164-170

\section{Introduction}

Central precocious puberty (CPP) is defined as the premature activation of the hypothalamic-pituitarygonadal axis (HPG) with the onset of breast development before 8 years of age in girls and an increase in testicular size in boys younger than 9 years of age that is progressive and accompanied by advancement of skeletal age and accelerated linear growth $(1,2,3)$. The phenomenon is much more common in girls than in boys $(4,5)$. On the other hand, idiopatic premature thelarche (PT) is relatively frequent and refers to the isolated development of the breasts before the age of 8 in girls without the activation of the HPG axis. Although most girls with premature thelarche will show spontaneous regression, there is a possibility of progression to true precocious puberty; therefore, it would be mandatory to discriminate between the puberty (precocious puberty) and prepubertal (premature thelarche) values of gonadotropins (6).

Laboratory measurement of gonadotropins, in particular luteinizing hormone (LH), after stimulation with GnRH or GnRH analog (GnRHa) is the standard https://ec.bioscientifica.com

https://doi.org/10.1530/EC-20-0651 (c) 2021 The authors Published by Bioscientifica Ltd

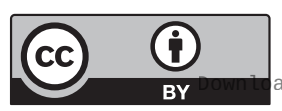

This work is licensed under a Creative Commons Attribution 4.0 International License. 
method to confirm HPG activity $(2,3,7)$. Currently, the value of $5 \mathrm{IU} / \mathrm{L}$ is accepted as the cut-off point when $\mathrm{LH}$ is determined by immunochemiluminescence assay ( 8 , $9,10,11,12)$. However, the development of additional sensitive immunoassays that measure gonadotropins in serum has motivated several authors to consider the utility of basal LH as a screening method $(9,13,14,15)$.

The objective of this study was to analyze whether some auxological characteristics or a single basal gonadotropin measurement will be sufficient to distinguish the prepubertal from pubertal hypothalamicpituitary-gonadal axis in girls with breast budding between 6 and 8-years old; and therefore the current method of gonadotropin response to GnRH stimulation could be omitted in many cases.

\section{Materials and methods}

\section{Participants}

This is a retrospective study carried out in a sample of 241 Caucasian girls aged 6 to 8 -years who were evaluated for early signs of puberty, such as breast budding, in the Pediatric Outpatient Endocrine Clinic of the Navarra Hospital Complex in Pamplona, Spain, between years 2015 and 2019. Breast development was assessed by both inspection and palpation and rating according to Tanner stage. All participants presented with Tanner stage 2 in breast development (appearance of the breast bud), and were followed up to at least 9 years of age.

The sample of girls was divided into two groups according to the GnRHa stimulation test results. Girls who had a peak LH values $\geq 5 \mathrm{IU} / \mathrm{L}$ were considered as having a pubertal activation of the HPG axis (CPP group), and girls who had lower values were considered prepubertal or premature thelarche (PT group). Patients previously diagnosed with gonadotropin-independent or peripheral precocious puberty were excluded.

Information recorded from every patient included family (paternal and maternal height, age of maternal menarche) and personal data (age at onset of breast budding, weight and height, BMI, and bone age), and GnRHa-stimulation testing results. Weight and height of all the participants had been previously recorded by the pediatrician at the Primary Health Care Center (periodical health checkup), and allowed the calculation of growth velocity $6-12$ months before the current clinical evaluation. Target height was calculated in centimeters using the formula: (maternal height + paternal height - 13)/2. Bone age (BA) and height-prognosis was determined using RUS-TW2 method (16).

Weight and height measurements were taken with participants wearing only undergarments and barefoot. Weight was measured using an Año-Sayol scale (reading interval $0-120 \mathrm{~kg}$ and a precision of $100 \mathrm{~g}$ ), and height was measured using a Holtain wall stadiometer (reading interval 60-210 cm, precision $0.1 \mathrm{~cm}$ ). BMI was calculated according to the following formula: weight $(\mathrm{kg}) /$ height $^{2}(\mathrm{~m})$.

The SDS values for the weight, height, BMI, and HV were estimated by applying the program Aplicación Nutricional, from the Spanish Society of pediatric gastroenterology, hepatology and nutrition (Sociedad Española de Gastroenterología, Hepatología y Nutrición Pediátrica, available at https://www.gastroinf.es/nutritional/). The graphics from Ferrández et al. (Centro Andrea Prader, Zaragoza 2002) were employed as reference charts (17).

\section{GnRH test}

GnRH test was accomplished at least once after 4 months of follow-up in both groups. GnRH stimulation test was performed by determining serum LH and FSH at baseline (between 8:00 $\mathrm{h}$ and 9:00 $\mathrm{h}$ after an overnight fast) and $4 \mathrm{~h}$ post subcutaneous administration of GnRH analog (leuprorelin, $500 \mu \mathrm{g}$ ). LH and follicular stimulating hormone (FSH) were measured by highly sensitive immunochemiluminescence assays (Immulite 2500) with a sensitivity of $<0.1 \mathrm{U} / \mathrm{L}$ for $\mathrm{LH}$ and FSH. Intra-assay coefficients of variation at $0.3 \mathrm{IU} / \mathrm{L}$ for $\mathrm{LH}$ were $3.5 \%$ and FSH $5 \%$. Baseline LH/FSH ratio and LH/FSH ratio post leuprorelin administration were calculated.

\section{Statistical analysis}

The parametric Student's $t$-test was used to compare the differences in variables recorded between PT and CPP groups. The receiver operating curves (ROC) were constructed after using the exact logistic regression models in order to evaluate the sensitivity and specificity of the auxological variables and basal gonadotropin levels based on predicted probability, and the area under the curve (AUC) was measured for each curve. Youden's J index, defined as ((sensitivity specificity) - 1), was used to determine the optimal cut point from the ROC curves to discriminate between PT from CPP girls. Statistical analyses were performed using the program Statistical Packages for the Social Sciences version 20.0 (Chicago, IL,

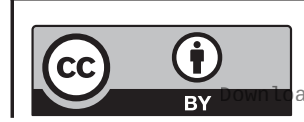

This work is licensed under a Creative Commons Attribution 4.0 International License. ded from Bioscientifica.com at 04/26/2023 12:59:07PM 
USA). Statistical significance was accepted when $P$-value was $<0.05$.

Parents and/or legal guardians were appropriately informed and gave consent for the participation of the participants in this study in all cases. This study was approved by the Ethics Committee for Human Investigation of the Navarra Hospital Complex, Pamplona, Spain (code: 19/07) in accordance with the ethical standards laid down in the 1964 Declaration of Hensinki and later amendments.

\section{Results}

Table 1 shows and compares mean values of family and personal data registered between PT (prepubertal) and CPP girls. Bone age advancement (BA-CA) are significantly higher in CPP girls $(P<0.05)$. There were no significant differences in target height, height prognosis, and maternal menarche, age at onset, weight, height, and BMI and height velocity between both groups.

The AUCs for bone age advancement $(0.59,95 \%$ CI: $0.51-0.67, P=0.016$ ) were significantly higher than 0.5 . Maximal Youden's J index was reached based on specificity of $52 \%$ and sensitivity of $64 \%$ for bone age advancement, and bone age advancement cut off point of 1.65 years was chosen to discriminate between PT (prepubertal) and CPP girls. In fact, $69.5 \%$ of the girls in

Table 1 Family and personal data of TP (prepubertal) and CPP girls $(M \pm S D S)$.

\begin{tabular}{|c|c|c|c|}
\hline Items & $\begin{array}{l}\text { PT girls } \\
(n=133)\end{array}$ & $\begin{array}{l}\text { CPP girls } \\
(n=108)\end{array}$ & $P$ values* \\
\hline Target height (cm) & $162.0 \pm 5.1$ & $161.1 \pm 5.5$ & 0.227 \\
\hline $\begin{array}{l}\text { Height prognosis } \\
(\mathrm{cm})\end{array}$ & $167.5 \pm 4.9$ & $166.5 \pm 5.2$ & 0.238 \\
\hline $\begin{array}{l}\text { Maternal menarche } \\
\text { (years) }\end{array}$ & $12.1 \pm 1.5$ & $11.8 \pm 1.3$ & 0.464 \\
\hline Age at onset (years) & $7.3 \pm 0.4$ & $7.4 \pm 0.3$ & 0.238 \\
\hline Weight (kg) & $30.4 \pm 6.6$ & $31.0 \pm 6.0$ & 0.52 \\
\hline Weight Z-score & $1.02 \pm 0.7$ & $1.03 \pm 0.9$ & 0.47 \\
\hline Height (cm) & $130.3 \pm 7.6$ & $132.1 \pm 8.2$ & 0.218 \\
\hline Height Z-score & $1.23 \pm 1.04$ & $1.36 \pm 1.2$ & 0.367 \\
\hline $\mathrm{BMI}\left(\mathrm{kg} / \mathrm{m}^{2}\right)$ & $18.1 \pm 2.7$ & $17.4 \pm 2.4$ & 0.09 \\
\hline BMI Z-score & $0.83 \pm 0.9$ & $0.91 \pm 0.9$ & 0.48 \\
\hline $\begin{array}{l}\text { Height velocity } \\
\text { (cm/year) }\end{array}$ & $6.8 \pm 1.3$ & $7.0 \pm 1.6$ & 0.666 \\
\hline $\begin{array}{l}\text { Height velocity } \\
\text { Z-score }\end{array}$ & $1.67 \pm 1.41$ & $1.90 \pm 1.73$ & 0.272 \\
\hline BA-CA (years) & $1.61 \pm 0.67$ & $1.82 \pm 0.71$ & 0.024 \\
\hline
\end{tabular}

the CPP group had a bone age advancement higher than 1.65 years (positive predictive value), while $52.6 \%$ of the girls in the prepubertal group had a bone age advancement lower than 1.65 years (negative predictive value).

Table 2 displays and compares the average values for basal and stimulated serum concentrations of gonadotropins ( $\mathrm{LH}, \mathrm{FSH}$, and $\mathrm{LH} / \mathrm{FSH}$ ratio) between PT (prepubertal) and CPP girls. Both basal LH and FSH and LH/FSH ratio means as well as the stimulated concentration of LH and FSH and the LH/FSH ratio were significantly higher in the CPP group than in the PT group $(P<0.01)$.

The AUCs and the optimal cut off point for discriminating PT (prepubertal) from CPP girls using a non-stimulated gonadotropin sample, (basal LH, FSH, and LH/FSH ratio) and based on sensitivity and specificity are shown in Table 3. The AUCs for basal LH, FSH and LH/FSH ratio were significantly higher than 0.5 , but the maximum predictability was reached using the basal $\mathrm{LH}$ with an AUC of 0.89 (Fig. 1). Maximal Youden's J index was reached based on specificity of $82 \%$ and sensitivity of $89 \%$ for basal LH, and LH cut off point of $0.1 \mathrm{IU} / 1$ was chosen to discriminate between CPP and prepubertal girls. In fact, $83 \%$ of the girls in the CPP group had a basal LH higher than $0.1 \mathrm{IU} / \mathrm{L}$ (positive predictive value), while $85 \%$ of the girls in the prepubertal group had a basal LH lower than $0.1 \mathrm{IU} / \mathrm{L}$ (negative predictive value). All girls in the CPP group had a basal LH higher than 1.0 IU/L (positive predictive value of 100\%). The basal FSH yielded less favorable performances such as sensitivity of $63 \%$ and specificity of $80 \%$ for a cut off point of $2.5 \mathrm{IU} / \mathrm{L}$.

Table 2 Basal and stimulated serum concentrations of gonadotropin of PT (prepubertal) and CPP girls ( $\mathrm{M} \pm \mathrm{SDS}$ ).

\begin{tabular}{|c|c|c|c|}
\hline Hormone & $\begin{array}{l}\text { PT girls } \\
(n=133)\end{array}$ & $\begin{array}{l}\text { CPP girls } \\
(n=108)\end{array}$ & P values* \\
\hline $\begin{array}{l}\text { Basal LH (UI/L) } \\
\text { (range) }\end{array}$ & $\begin{array}{r}0.06 \pm 0.09 \\
(\mathbf{0 . 0 1 - 1 . 0 3 )}\end{array}$ & $\begin{array}{r}0.61 \pm 0.94 \\
(\mathbf{0 . 0 1 - 4 , 1 4 )}\end{array}$ & 0.001 \\
\hline $\begin{array}{l}\text { LH peak (UI/L) } \\
\text { (range) }\end{array}$ & $\begin{array}{l}2.20 \pm 1.14 \\
(0.01-4.75)\end{array}$ & $\begin{array}{l}12.89 \pm 5.34 \\
(6.09-28.42)\end{array}$ & 0.001 \\
\hline $\begin{array}{l}\text { Basal FSH (UI/L) } \\
\text { (range) }\end{array}$ & $\begin{array}{r}1.49 \pm 0.92 \\
(\mathbf{0 . 1 0}-\mathbf{4 . 8 5 )}\end{array}$ & $\begin{array}{r}3.34 \pm 1.82 \\
(\mathbf{0 . 4 4 - 0 . 9 1 )}\end{array}$ & 0.001 \\
\hline $\begin{array}{l}\text { FSH peak (UI/L) } \\
\text { (range) }\end{array}$ & $\begin{array}{l}15.03 \pm 6.48 \\
(\mathbf{0 . 2 7}-\mathbf{2 9 . 5 3 )}\end{array}$ & $\begin{array}{l}18.90 \pm 6.73 \\
(\mathbf{8 . 2 4 - 3 4 . 7 1 )}\end{array}$ & 0.001 \\
\hline $\begin{array}{l}\text { Basal LH/FSH ratio } \\
\text { (range) }\end{array}$ & $\begin{array}{c}0.042 \pm 0.388 \\
(\mathbf{0 . 0 1 - 0 . 2 4 )}\end{array}$ & $\begin{array}{l}0.16 \pm 0.155 \\
\mathbf{( 0 . 0 1 - 0 . 8 )}\end{array}$ & 0.001 \\
\hline $\begin{array}{l}\text { LH peak/FSH } \\
\text { peak ratio } \\
\text { (range) }\end{array}$ & $\begin{array}{c}0.156 \pm 0.131 \\
(\mathbf{0 . 0 4 - 1 . 3 6 )}\end{array}$ & $\begin{array}{r}0.755 \pm 0.53 \\
(\mathbf{0 . 1 9}-\mathbf{3 . 3 0 )}\end{array}$ & 0.001 \\
\hline
\end{tabular}

Values in bold (except $12.89 \pm 5.34$ ) correspond to the range (minimum value and maximum value)

*Student's $t$-test.

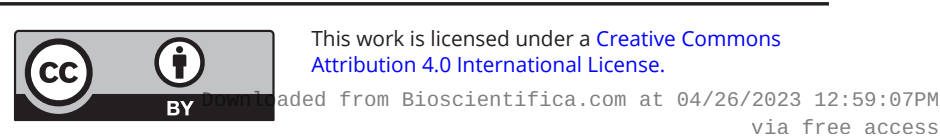


Table 3 Sensitivity and specificity for selected cut off point values of basal gonadotropin level discriminating CPP from PT girls, calculated by ROC.

\begin{tabular}{|c|c|c|}
\hline Hormone & AUC $(95 \% \mathrm{Cl})$ & $\mathbf{P}$ \\
\hline $\mathrm{LH}$ & $0.89(0.84-0.93)$ & 0.001 \\
\hline FSH & $0.80(0.75-0.85)$ & 0.001 \\
\hline LH/FSH ratio & $0.82(0.76-0.88)$ & 0.001 \\
\hline
\end{tabular}

The sensitivity and specificity for the basal LH/FSH ratio values were 73 and $74 \%$, respectively, for a cut off point of 0.05 . That is, there was a wide overlap of basal FSH and $\mathrm{LH} / \mathrm{FSH}$ ratio between prepubertal and pubertal girls.

\section{Discussion}

This study features that auxological characteristics represent a weak predictor for GnRH-dependent PP and should not be used only in the differential diagnosis between PT and CPP in 6- to 8-year-old girls. However, we found a high specificity of a single basal LH sample and it would be useful for establishing the diagnosis of CPP in this age group.

Most cases of premature thelarche present in the first four years of life and regress before puberty, but girls who present later may be accompanied by accelerated growth and advanced bone age. The name given to this condition by several authors was 'slowly progressive variant of

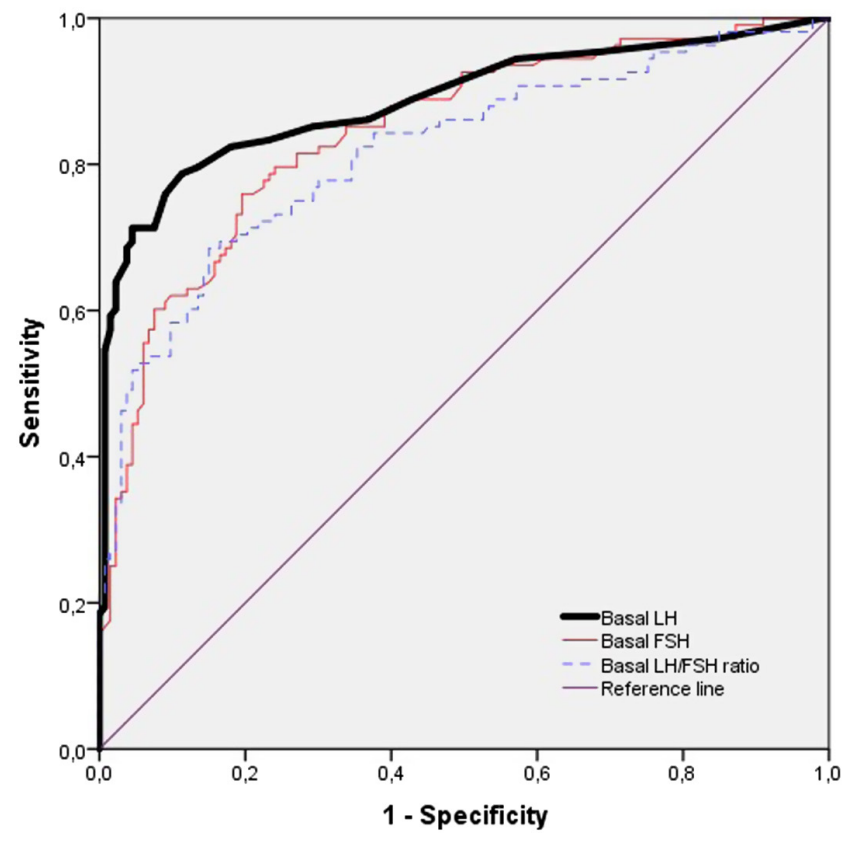

Figure 1

ROC curves used to evaluate the sensitivity and specificity of basal gonadotropin (LH, FSH and LH/FSH ratio). precocious puberty' associated with both basal and GnRHstimulated serum LH levels of prepubertal characteristics $(2,10)$. Our data show that most of the auxological characteristics recorded overlapped between girls with PT and CPP aged 6-8 years. In fact, there were no significant differences in weight, height, BMI, and growth velocity between both groups; only advanced bone age emerged as a significant predictor of CPP in this age group, although with limited discriminatory capacity (positive predictive value: $69.5 \%$ ). Therefore, an exclusive measurement of the auxological characteristics would not be sufficient to diagnose or exclude CPP in girls with breast budding in this age range (18). In addition, it should be noted that the prognosis of adult height of the CPP girls, which at the time of diagnosis is usually overvalued by clinical and auxological conditions (19), did not differ from that calculated for the PT girls.

Diagnosis of CPP is based on clinical evaluation and laboratory hormonal assessment. Different hormone assays with high sensitivity to measure gonadotropins levels are currently available, such as immunofluorometric, immunochemiluminiscence (ICMA) or electrochumiluminescence. But ICMA is the most commonly used - it has also been used in this study - and allows reasonable discrimination between prepubertal and pubertal status using a single basal LH level (11). The distinct cut-off values of basal LH assessed by ICMA that indicate HPG axis activation varies according to the different authors, and oscillate between 0.1 and $1.1 \mathrm{IU} / \mathrm{L}(9,10,13,20,21)$. Caution should be used when interpreting gonadotropin concentrations in girls in the first three years of life, because basal gonadotropin concentrations are usually high in this age group (22). Our results, carried out in a larger cohort in girls aged $6-8$ years, confirm the high sensitivity $(82 \%)$ and specificity $(90 \%)$ of a single basal LH sample for establishing the diagnosis of CPP when basal LH sample was higher than $0.1 \mathrm{IU} / \mathrm{L}$, with a positive predictive value of $83 \%$. However, the positive predictive value of $100 \%$ obtained in this study from a single baseline LH sample was obtained with a cut-off point of $1.0 \mathrm{IU} / \mathrm{L}$. Since the sensitivity and specificity of a single basal LH sample for the diagnosis of CPP varies in relation to cut-off value and

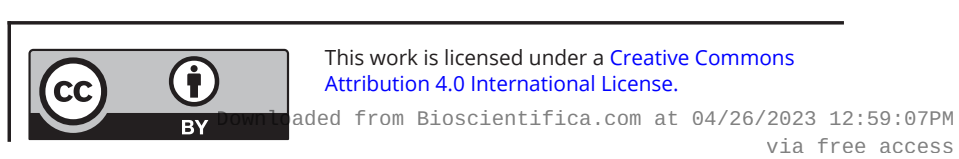


laboratory methodology $(11,12)$, several authors have recommended blood sample collection to obtain normal basal values of gonadotropins in clinical centers that care for girls with $\operatorname{CPP}(7,8,9)$.

As both gonadotropin determinations (basal LH, FSH and $\mathrm{LH} / \mathrm{FSH}$ ratio) are supposed to be increased in the HPG axis activation, they have been routinely measured during the evaluation of CPP and, in fact, both have discriminatory capacity between CPP and prepubertal girls. However, as several authors have described $(9,10$, $13,14,15)$, this study found that the measurement of basal FSH concentrations or basal LH/FSH ratio do not improve diagnostic sensitivity over basal LH alone in girls aged 6-8 years undergoing evaluation for CPP. This lower discriminatory capacity observed in basal FSH and $\mathrm{LH} / \mathrm{FSH}$ ratio seems to derive from the overlap of the FSH levels observed in girls with and without CPP. Serum levels of estradiol are not used to diagnose CPP, considering their low sensitivity and large overlap between normal prepubertal and pubertal children (11). Nevertheless, novel laboratory techniques such as tandem mass spectrometry might improve the sensitivity and specificity of estradiol assays (23). In fact, different authors have described that GnRHa-stimulated serum estradiol level at $24 \mathrm{~h}$ may be a useful indicator of pubertal activation, regardless of the LH values $(21,24)$. However, GnRH-stimulated serum LH level provides the best clinical model due to its practicality and convenience when evaluating puberty in girls.

In the present study, we found that a basal LH level greater than $0.1 \mathrm{IU} / \mathrm{L}$ would be suggestive of central pubertal activation (positive predictive value of $83 \%$ ) in those girls who have breast budding accompanied by physical suspicion of precocious puberty (accelerated growth rate and, especially, bone age advancement). However, if LH level was greater than 1.0 IU/L (positive predictive value of $100 \%$ ), a diagnosis of CPP can be made, avoiding the inconvenience, costs and time of the GnRH stimulation test. Thus, a sample for basal LH measurement could be obtained by the primary care physician for initial management: a LH level higher than $0.1 \mathrm{IU} / \mathrm{L}$, would mean a reasonable suspicion of puberty status that should be confirmed by GnRH stimulation; if basal LH level was higher than 1.0 IU/L, the girl should be referred for additional assessment concerning the etiology of precocious puberty and to determine adequate treatment by the pediatric endocrinologist. In contrast, baseline $\mathrm{LH}$ levels are not sufficiently sensitive to rule out CPP in girls whose baseline LH levels are <0.1 IU/L; furthermore, even if the basal levels of LH were undetectable in the presence of clinical signs of progressive pubertal development, the stimulation test would be necessary for the identification of hypothalamic-pituitary-gonadal axis activation. In this way, an algorithm for the diagnosis of CPP was proposed for our endocrinology unit (Fig. 2) based on the data obtained in this study. Patients should be followed on a quarterly basis until at least 9 years of age in order to exclude possible advanced puberty.

There are certain limitations in the diagnostic sensitivity of basal LH levels. Indeed, 17\% of the girls who had CPP in our cohort had an initial LH concentration of $<0.1 \mathrm{IU} / \mathrm{L}$. This absence of concordance between the GnRHa stimulation tests with the basal level of LH could be due to the fact that the girls had been evaluated at an early stage of puberty, since in the first months of pubertal development hypothalamic-pituitary-gonadal axis activation is progressive and even oscillating (10). In fact, in 15 cases out of the 108 girls with CPP included in this study (14\%), a previous GnRHa test was performed with a prepubertal result, but with a subsequent pubertal progression. However, it is possible that some of our patients who presented with PT represent slowly progressing variants of CPP (2). Another limitation is that girls with peripheral sexual precocity have suppressed basal LH levels. That is, the presence of a high concentration of estradiol with low basal gonadotropins together with a rapid development of secondary sexual characteristics should compel to investigate for peripheral causes (adrenal or ovarian tumors, exposure to exogenous sex

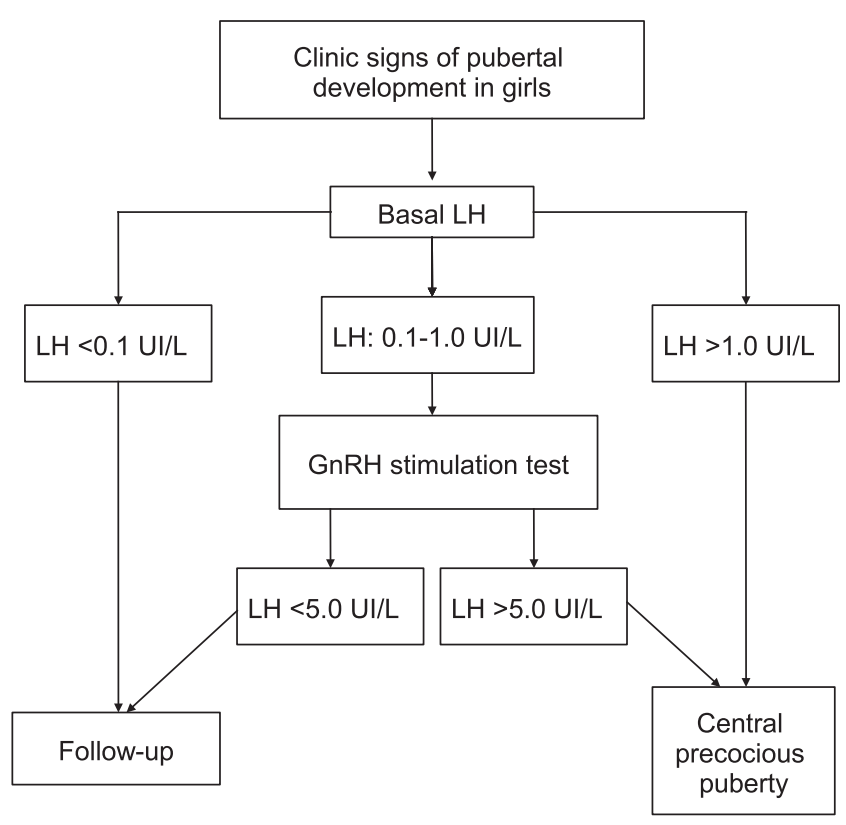

Figure 2

Algorithm proposed for the diagnosis of central precocious puberty.

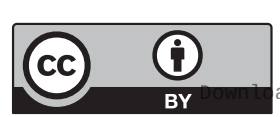

This work is licensed under a Creative Commons Attribution 4.0 International License. ded from Bioscientifica.com at 04/26/2023 12:59:07PM 
steroids, etc.). Furthermore, due to the diurnal fluctuation of gonadotropin levels, especially in early puberty, the evaluation of basal serum LH levels would be debatable (15). Despite these restrictions, we found that a basal LH level greater than $0.1 \mathrm{UI} / \mathrm{L}$ in girls is highly suggestive of central pubertal activation, whereas an undetectable LH value does not exclude a GnRHa test.

In conclusion, we support that, in the majority of girls aged 6 to 8 years presenting with premature thelarche, a single basal LH determination would be of high diagnostic usefulness in identifying girls who have CPP, so reducing the need for GnRH stimulation testing. Basal FSH concentrations or basal LH/FSH ratio do not improve diagnostic sensitivity in girls undergoing evaluation for CPP. However, clinical judgment and follow-up continue to be of greater importance in the evaluation of this entity.

\section{Declaration of interest}

The authors declare that there is no conflict of interest that could be perceived as prejudicing the impartiality of the research reported.

\section{Funding}

This work did not receive any specific grant from any funding agency in the public, commercial, or not-for-profit sector.

\section{Author contribution statement}

T D T and F G V participated in study design and data analysis, and wrote the first draft of the manuscript. M M C, L A M, S B Z and M C G participated in data collection and analysis. All authors participated in manuscript preparation and approved its final version.

\section{References}

1 Parent AS, Teilmann G, Juul A, Skakkebaek NE, Toppari J \& Bourguignon JP. The timing of normal puberty and the age limits of sexual precocity: variations around the world, secular trends, and changes after migration. Endocrine Reviews 200324 668-693. (https:// doi.org/10.1210/er.2002-0019)

2 Dattani MT \& Hindmarsh PC. Normal and abnormal puberty. In Clinical Pediatric Endocrinology, ch. 10, 5th ed., pp. 183-210. Eds CGD Brook, PR Clayton \& RS Brown. Boston, MA, USA: Blackwell Publishing, 2005.

3 Carel JC \& Léger J. Clinical practice. Precocious puberty. New England Journal of Medicine 2008358 2366-2377. (https://doi.org/10.1056/ NEJMcp0800459)

4 Soriano-Guillén L, Corripio R, Labarta JI, Cañete R, Castro-Feijóo L, Espino R \& Argente J. Central precocious puberty in children living in Spain: incidence, prevalence, and influence of adoption and immigration. Journal of Clinical Endocrinology and Metabolism 201095 4305-4313. (https://doi.org/10.1210/jc.2010-1025)

5 Rohani F, Salehpur S \& Saffari F. Etiology of precocious puberty, 10 years study in Endocrine Reserch Centre (Firouzgar), Tehran. Iranian Journal of Reproductive Medicine 201210 1-6.

6 Varimo T, Huttunen H, Miettinen PJ, Kariola L, Hietamäki J, Tarkkanen A, Hero M \& Raivio T. Precocious puberty or premature thelarche: analysis of a large patient series in a single tertiary center with special emphasis on 6- to 8-year-old girls. Frontiers in Endocrinology 20178 213. (https://doi.org/10.3389/ fendo.2017.00213)

7 Bangalore Krishna K, Fuqua JS, Rogol AD, Klein KO, Popovic J, Houk CP, Charmandari E, Lee PA, Freire AV, Ropelato MG, et al. Use of gonadotropin-releasing hormone analogs in children: update by an international consortium. Hormone Research in Paediatrics 201991 357-372. (https://doi.org/10.1159/000501336)

8 Mogensen SS, Aksglaede L, Mouritsen A, Sørensen K, Main KM, Gideon P \& Juul A. Diagnostic work-up of 449 consecutive girls who were referred to be evaluated for precocious puberty. Journal of Clinical Endocrinology and Metabolism 201196 1393-1401. (https:// doi.org/10.1210/jc.2010-2745)

9 Pasternak Y, Friger M, Loewenthal N, Haim A \& Hershkovitz E. The utility of basal serum LH in prediction of central precocious puberty in girls. European Journal of Endocrinology 2012166 295-299. (https:// doi.org/10.1530/EJE-11-0720)

10 Harrington J, Palmert MR \& Hamilton J. Use of local data to enhance uptake of published recommendations: an example from the diagnostic evaluation of precocious puberty. Archives of Disease in Childhood 201499 15-20. (https://doi.org/10.1136/ archdischild-2013-304414)

11 Brito VN, Spinola-Castro AM, Kochi C, Cristiane Kopacek C, Alves da Silva PC \& Guerra-Junior G. Central precocious puberty: revisiting the diagnosis and therapeutic management. Archives of Endocrinology and Metabolism 201660 163-172. (https://doi: 10.1590/23593997000000144)

12 Latronico AC, Brito VN \& Carel JC. Causes, diagnosis, and treatment of central precocious puberty. Lancet: Diabetes and Endocrinology 2016 4 265-274. (https://doi.org/10.1016/S2213-8587(15)00380-0)

13 Houk CP, Kunselman AR \& Lee PA. Adequacy of a single unstimulated luteinizing hormone level to diagnose central precocious puberty in girls. Pediatrics 2009123 e1059-e1063. (https://doi.org/10.1542/peds.2008-1180)

14 Lee HS, Park HK, Ko JH, Kim YJ \& Hwang JS. Utility of Basa luteinizing hormone levels for detecting central precocious pubertyin girls. Hormone and Metabolic Research 201244 851-854. (https://doi. org/10.1055/s-0032-1321905)

15 Carretto F, Salinas-Vert I, Granada-Yvern ML, Murillo-Vallés M, Gómez-Gómez C, Puig-Domingo M \& Bel J. The usefulness of the leuprolide stimulation test as a diagnostic method of idiopathic central precocious puberty in girls. Hormone and Metabolic Research 201446 959-963. (https://doi.org/10.1055/s-0034-1387790)

16 Tanner JM, Whitehouse RH, Marshall WA, Healy MJR \& Goldstein H. Assessment of Skeletal Maturity and Prediction of Adult Height (TW2 Method), 2nd ed. London: Academic Press, 1983.

17 Ferrández A, Baguer L, Labarta JI, Labena C, Mayayo E, Puba B, Rueda C \& Ruiz-Echarri M. Longitudinal pubertal growth according to age at pubertal study of normal Spanish children from birth to adulthood. Pediatric Endocrinology Reviews 20052 423-559.

18 Lee DM \& Chung IH. Morning basal luteinizing hormone, a good screening tool for diagnosing central precocious puberty. Annals of Pediatric Endocrinology and Metabolism 201924 27-33. (https://doi. org/10.6065/apem.2019.24.1.27)

19 Durá-Travé T, Ortega-Pérez M, Ahmed-Mohamed L, MorenoGonzález P, Chueca-Guindulain MJ \& Berrade-Zubiri S. Central precocious puberty in girls: diagnostic study and auxological response to triptorelin treatment. Endocrinología, Diabetes y Nutrición 20196 410-416. (https://doi: 10.1016/j.endinu.2018.12.007)

20 Neely EK, Hintz RL, Wilson DM, Lee PA, Gautier T, Argente J \& Stene M. Normal ranges for immunochemiluminometric gonadotropin assays. Journal of Pediatrics 1995127 40-46. (https:// doi.org/10.1016/s0022-3476(95)70254-7)

21 Sathasivam A, Garibaldi L, Shapiro S, Godbold J \& Rapaport R. Leuprolide stimulation testing for the evaluation of early female https://ec.bioscientifica.com https://doi.org/10.1530/EC-20-0651 (c) 2021 The authors Published by Bioscientifica Ltd

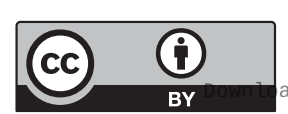

This work is licensed under a Creative Commons Attribution 4.0 International License. ded from Bioscientifica com at 04/26/2023 12:59:07PM 
sexual maturation. Clinical Endocrinology 201073 375-381. (https:// doi.org/10.1111/j.1365-2265.2010.03796.x)

22 Bizzarri C, Spadoni GL, Bottaro G, Montanari G, Giannone G, Cappa M \& Cianfarani S. The response to gonadotropin releasing hormone $(\mathrm{GnRH})$ stimulation test does not predict the progression to true precocious puberty in girls with onset of premature thelarche in the first three years of life. Journal of Clinical Endocrinology and Metabolism 201499 433-439. (https://doi.org/10.1210/jc.2013-3292)
23 Ketha H, Kaur S, Grebe SK \& Singh RJ. Clinical applications of LC-MS sex steroid assays: evolution of methodologies in the 21st century. Current Opinion in Endocrinology, Diabetes, and Obesity 201421 217-226. (https://doi.org/10.1097/MED.0000000000000068)

24 Chin VL, Cai Z, Lam L, Shah B \& Zhou P. Evaluation of puberty by verifying spontaneous and stimulated gonadotropin values in girls. Journal of Pediatric Endocrinology and Metabolism 201528 387-392. (https://doi.org/10.1515/jpem-2014-0135)

Received in final form 23 December 2020

Accepted 6 January 2021

Accepted Manuscript published online 9 January 2021

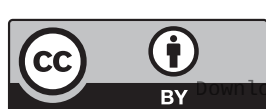

This work is licensed under a Creative Commons Attribution 4.0 International License.

ded from Bioscientifica.com at 04/26/2023 12:59:07PM via free access 